\title{
Determinants of construction sector profitability in Croatia*
}

\author{
Lorena Škuflić ${ }^{1}$, Danijel Mlinarić2 ${ }^{2}$ Marko Družicí
}

\begin{abstract}
This paper examines the determinants of profitability for construction companies in Croatia. Sample includes more than 8678 construction companies covering the period from 2003 to 2014 what present 11 years of observation including Croatian milestone in joining to the European Union as well as global financial crises. The authors analyze theoretical background and use empirical research to investigate the relation between profitability and selected determinants like price cost margin, concentration index, growth, size, material costs and lagged profitability. Special remarks are given with review of construction sector importance for the growth of the Croatian economy and repercussions of global financial crises. According to that, for the empirical part of the article generalized method of moments for dynamic panel model has been used which has given significant results. Overall, the results have proved a strong relationship between company size, concentration index, growth, lagged profitability and profitability besides number of employees.
\end{abstract}

Key words: construction sector, profitability, Croatia, panel data analysis

JEL classification: L21, L25, L74

\footnotetext{
* Received: 14-06-2017; accepted: 30-05-2018

1 Full professor, University of Zagreb, Faculty of Economics and Business, J. F. Kennedy Sq. 6, 10000 Zagreb, Croatia. Scientific affiliation: industrial organization, competitiveness. Phone: +38512383115.E-mail:lskuflic@efzg.hr.

2 Assistant professor, University of Zagreb, Faculty of Economics and Business, J. F. Kennedy Sq. 6, 10000 Zagreb, Croatia. Scientific affiliation: industrial organization, systemic risk, banking system competitiveness.Phone: +38512383 127.E-mail:dmlinaric@efzg.hr.

3 Assistant professor, University of Zagreb, Faculty of Economics and Business, J. F. Kennedy Sq. 6, 10000 Zagreb, Croatia. Scientific affiliation: microeconomics. Phone: +38512383129. E-mail:mdruzic@efzg.hr.
} 


\section{Introduction}

Croatian construction sector is a dynamic and volatile industry regarding increasing uncertainties in local and world construction doing business. It takes one of the significant industry influence on Croatian domestic economy, especially in the period between 2000 and 2008, before the global financial crises began. That was a period with the highest growth rate of construction sector with a major contribution to the Croatian GDP. The growth rate has significantly increased from 4,2 in 2000 to 7,2 in 2008 in total contribution with an increase of sector employment in the same period for 61,1 percent. Consequently, all other connected sectors took impulse of that significant growth which also gives construction sector reasons for research, especially from 2009 until today when analysis of available accounts indicates long-run drop. In mentioned period, the construction industry has struggled to recover to the pre-financial crisis levels. Building on previous studies, the impact of determinants on financial result among other countries in the selected period, gave different conclusions according to the sample structure and data quality. Moreover, company performance in observed countries gives different consequences for construction policy modeling. There are obviously challenges and risks according to the construction business environment due to uncertainties in state construction policy, technology, development process and internal and external financial pressure. Finding those determinants will bring significant benefits to stakeholders of observed firms, specifically management boards, investors, shareholders, creditors, and policymakers. All mentioned reasons give inspiration for this investigation that has data basis from FINA database for more than 8500 Croatian construction companies in period of 2003 to 2014.

There have been many papers recently that test firms' profitability for every type of industry. Based on previous papers and conclusions, the aim of this paper is to find factors that significantly influence the profitability of construction companies in Croatia, dominantly for firms under and above of 250 employees. That research question will give an answer which determinants are importer than others with sign of influence and show a clear picture of company size importance. The paper investigates net profit after tax as a proxy for profitability and its connection with selected determinants. One of most appropriate measure of a firm perspective is firm profitability. Without profitability, the firm cannot grow, and if it doesn't grow, then its stock will decline. Positive profit rate is one of the best indications that a firm is capable of long-run growth and to pay dividends and that the share price will increase. Creditors will rather loan money at the lowest rate to a profitable company, than to an unprofitable one; consequently, profitable companies can use leverage to increase stockholders' equity even more. According to all mentioned above, it is important to understand what drives firm profitability so that stakeholders may recognize and implement appropriate business policy with good investment decisions. This is an important topic especially in Croatia in which construction sector is an important 
part of country's gross domestic product. It can be defined as dynamic and complex industry sector because of all characteristics which influence it.

The article proceeds as follows. In the introduction, we introduce and explain domain and the main goal of the article. Section 2 provides a brief overview of the theoretical background relating to the determinants of profitability of previous researchers. Section 3 consists of an explanation of construction sector in Croatia with special remarks on its significance for GDP and declining in crises period and review of used methodology. Further, next 4th Section provides empirical data and analysis. Section 5 gives the sublimated results of dynamic panel data model with the explanation of chosen variables. In the end, in Section 6, final remarks are given in this article and further recommendations.

\section{Literature review}

The correlation between company profitability and its determinants are considered by following studies. According to Škuflić, Mlinarić, and Družić (2016) one of the most frequent research questions is the main determinant of firm profitability unconnected to the firms' essence. From that point of view, models of firm profitability are known as structure-conduct-performance (SCP) and firm effect models. In the structure-conduct-performance model, the market structure determines firm behavior and profitability. In firm effect models, market structure is the result of the distribution of firms and firm profits. Industrial organization economics has proven extremely useful to researchers of strategy content in providing a elementary theoretical perspective on the correlation of market structure on firm strategy and performance (Stierwald, 2009). There has been a range variety of different models, we can put main determinants of firm-level profitability on three parts: (1) industry characteristics in which the firm competes; (2) the firm's position relative to its competitors; (3) the quantity and quality of the firm's resources (Hansen and Wernerfelt, 1989). In the paper of Scherer (1980) many of the special models of both firm- and industry- level performance, and Porter's review (1981) describes the influence of the Industrial Organization paradigm in management and business policy. A long tradition, most often associated with Bain (1956) is concerned with identifying properties of industries contributing to profitability which is under average. Many of variables, for example, growth, advertising intensity, concentration, capital intensity, etc. have performed differently in different papers, but the overall importance of these factors is beyond dispute (Ravenscraft, 1983). Stierwald (2010) and Yazdnafar (2013) also investigates factors that have a correlation with profitability.

Schmalensee (1989), McGahan and Porter (2002) also conclude that there has been a substantial amount of empirical research undertaken in the area of profits, market 
structure, and firm-level effects, today in the 21 st Century it is undoubtedly clear fact, what confirms all actual scientific researchers. Taken together, the evidence suggests that both SCP and firm effect models are reputed. This implies that industry effects, such as concentration, and firm effects, such as productivity differences are empirically significant. Build upon on the study, firm-level or industry-level effects are based to be the important factor in firm profitability (Stierwald, 2009: 4). After all, Figure 1 gives theoretical sublimation and classification of determinants which have an impact on firms' profitability.

Figure 1: Firm profitability determinants

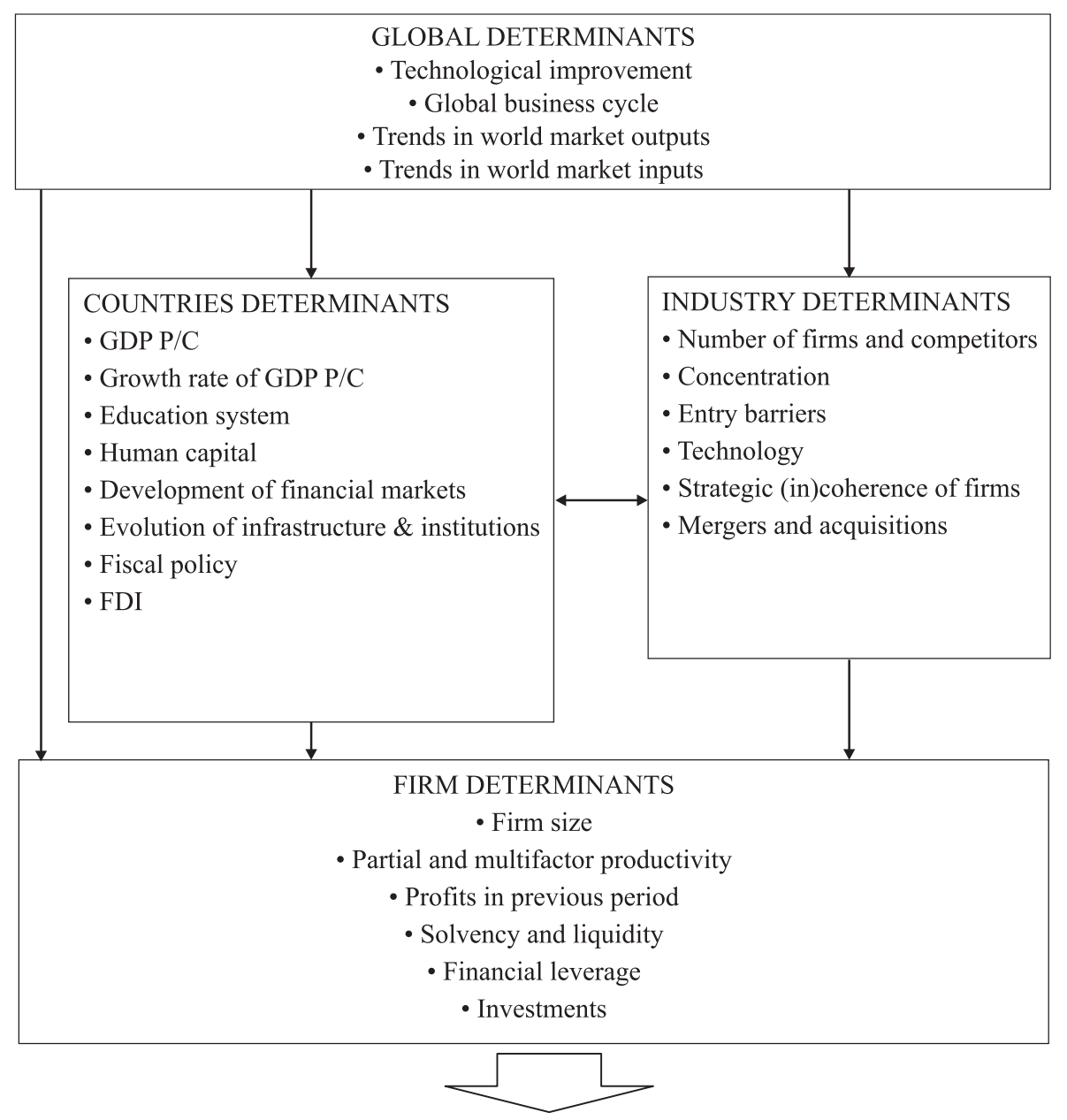

\section{P R O F I T A B I L I T Y}

Source: Customized on basis of Škuflić, L., Mlinarić, D. (2015) „Microeconomic determinants of profitability for Croatian hotel industry", Economic review, Vol. 5, No. 5, p. 482 


\section{Methodology}

The framework of generalized method of moments (GMM) is common practice in empirical work and it is proposed by Arellano and Bond (1991), Arellano and Bover (1995), and Blundell and Bond (1998), amongst others. Therefore, and because of dynamic nature of relations in the construction industry where present values depend on past results, it is understandable to use GMM. Only dynamic models are explaining relations in which dependent variable with one or more lags depends on independent variable performance. Dynamic panel model where dependent variable has one lag is:

$y_{i t}=\mu+\gamma y_{i, t-1}+\beta_{1} x_{i t 1}+\beta_{2} x_{i t 2}+\ldots+\beta_{\mathrm{k}} x_{i t k}+\alpha_{i}+\varepsilon_{i t} i=1, \ldots, N ; t=1, \ldots, T$

where $\varepsilon_{i t}$ is relation error with independent and identity distributed random variable with medium 0 and variance $\sigma_{\delta}^{2}$.

The Arellano-Bond estimator sets up a generalized method of moments (GMM) problem in which the model is specified as a system of equations, one per time period, where the instruments applicable to each equation differ (for instance, in later time periods, additional lagged values of the instruments are available). According to the previous generalized model, the Arellano-Bond estimator is defined as:

$$
y_{i t}=\gamma y_{i, t-1}+\alpha_{i}+\varepsilon_{i t}, i=1, \ldots, N ; t=1, \ldots, T
$$

where are $\varepsilon_{i t}$ a relation error with independent and identity distributed random variable with medium 0 and variance $\sigma_{\delta}^{2}$, and $\alpha_{i}$ is fixed or random effect different for every identity in a sample. Model based on previous theoretical explanation for this research is:

$$
\begin{aligned}
& \text { net_profit_af_tax }{ }_{i t}=\mu+\text { rnet_profit_af_tax } x_{i, t-1}+\beta_{1} \operatorname{logassets}_{i t}+ \\
& +\beta_{2} \text { hhi }_{i t}+\beta_{3} \text { salesgrowth }_{i t}+\beta_{4} \text { pcm }_{i t}+\beta_{5} \text { mater_costs }_{i t}+\alpha_{i}+\varepsilon_{i t} \text {; } \\
& i=1, \ldots, 11, t=2003, \ldots, 2014
\end{aligned}
$$

The validity of instrumental variables is tested with Sargan test (or Sargan-Hansen or just Hansen) and Arellano-Bond test. In attempts for better study results of the determinants of construction firm profitability dummy variables were introduced. Dummies represent the size of firms according to the number of employees. Usually, the national classification for small and big firms is 250 employees. According to that point, this sample is divided among 250 employees, for below 250 dummy $=0$, and for above 250 dummy $=250$. In the group with more than 250 employees (dummy $=1$ ) there are 59 firms with 357 observations, and in a group with less than 250 employees, there are 8619 firms with 55972 observations. Table 2 shows results which have been analyzed using STATA 11 program which includes Sargan and A-B tests. 


\section{Empirical data and analysis}

\subsection{Descriptive analysis of construction sector in Croatia}

Global construction industry market is a large, expanding, divided, regionally fluctuating, heterogeneous and involves risks with numerous of competitors. In order to compete and grow on the international market, filled with opportunities and threats, they must constantly increase their competitiveness, find a good way of entering targeted markets and risk management connected to the international construction projects, especially with business in transition economies. The construction sector has a tendency of following the GDP, but specific policy and government interventions have a specific influence. The global construction market is characterized by a slow post-recession recovery, where only Europe had a decrease in the market in 2012. Forthcoming points are infrastructure and energetics, where developing markets have biggest chances for growth.

After the second recession, USA market started to level off but from a low starting point. Growth was initiated by private sector where housing building is still low. In the USA, in 2012, growth was at 6\%. The construction market in Europe had a negative growth of $-2 \%$, crises in indebted countries and low civil engineering. In the last few years, only Germany and Scandinavian countries have exhibited growth. Transition countries in Asia achieved growth, although not as high as before. China and India have exhibited relative stagnation, while other transition countries in Asia have achieved growth. In the center of the 6\% growth in these countries were infrastructure building and work in the sector of energetics. Brazil is dominant in the construction market in Latin America, due to the Olympic Games and football World cup, with most of the work in infrastructure and energetics sector. Long-term growth and construction development are expected on the mentioned market. The Middle East and African market are unstable and unpredictable, despite the high growth. Russia prevails on construction markets in CIS countries, but its business activity correlates with the oil prices. Markets of small countries differ widely, depending on oil or natural gas as the source of their financing. The growth rate of the construction market, in CIS countries, was $4 \%$.

Financial and economic crises had a strong impact on the construction industry in almost every EU country. Output and employment had a significant drop in many countries, especially in Spain and Baltic countries. From the start of 2008 until the end of 2010 seasonally adjusted index of production had fallen for more than a fifth, increasing the length and intensity of the depression. Although the first quarter had shown moderate recovery, rest of the year had not shown any signs of sustainable long-term growth. In February 2012 output level of construction had lapsed below the level it was on in the financial and economic crisis, after which it had stabilized 
onward from May 2012. Construction activity has a seasonal character in many EU members, therefore it relates to the economic cycle. As a supplier of tangible assets it usually impacts the whole economy, although that was not the case in this financial and economic crisis as the construction activity continued to fall long after other activities had relapsed.

Figure 2: GVA (Gross Value Added) of construction industry in GDP - in $\%$

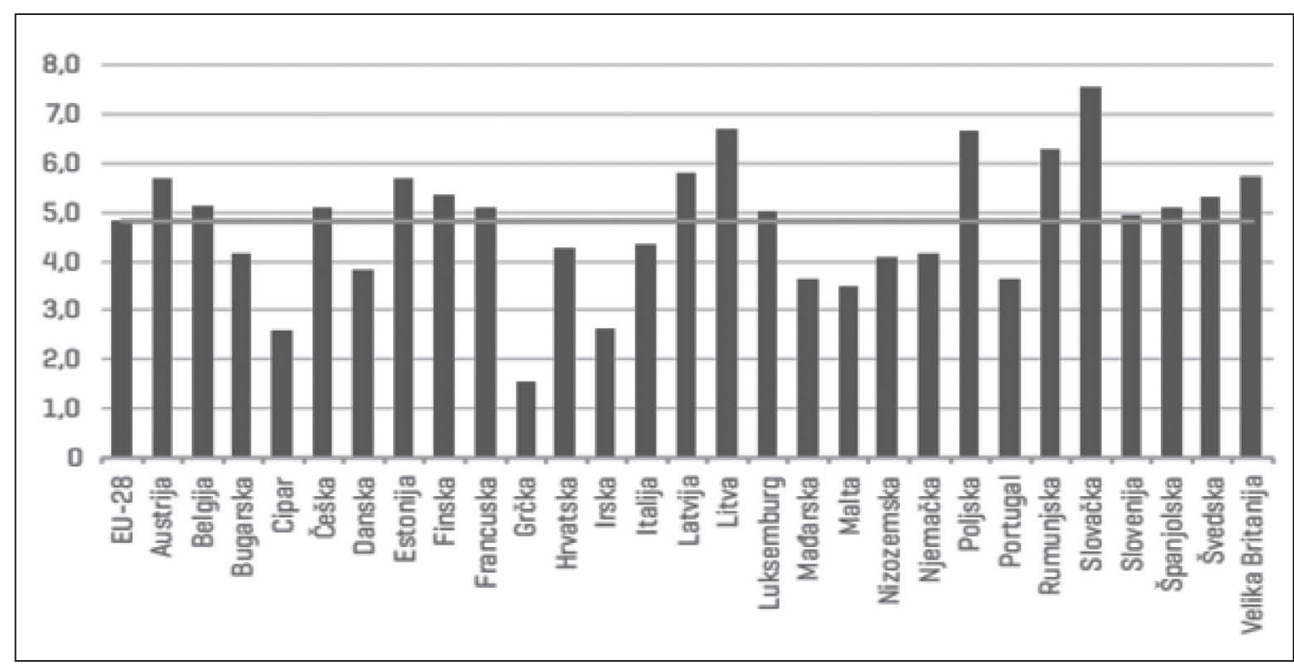

Source: Sector Analyses (X/2015) The Institute of Economics, Zagreb - Croatia, Vol. 40(4), p. 8

Figure 2 shows the contribution of construction sector for GDP in EU countries including Croatia for comparison. It is obvious that transition countries like Poland, Slovakia, Latvia, Lithuania, and Romania have the biggest contribution of the construction sector to gross domestic production while Croatia is below EU average with a share below $4,5 \%$ of the construction sector in GDP. Figure 3 shows the share of the construction sector in GDP in Croatia and average of EU-28.

From 2010 to 2012 the construction industry in Croatia had gone through significant changes in a number of firms on the market. In 2010 there were 10.759 active firms, in 2011 that number had increased by 1.592 resulting in a total number of 12.351 active firms on the market. In 2012 that number suddenly dropped but it had still been higher than in 2010 (total of 11.826 active firms). That translates to a relative increase in active firms by $9,92 \%$ from 2010 to 2012. Another significance for the industry was a constantly falling employment, it had dipped from 90.842 in 2010 to 79.926 in 2012, in other words, it had decreased by 10.916 employees $(12,02 \%)$ which is shown in Figure 4. Specialized construction branch F43 suffered the most in terms of employment with an average decrease of $38,50 \%$ per firm. 
Figure 3: Contribution of Construction industry in GDP in Croatia and EU-28

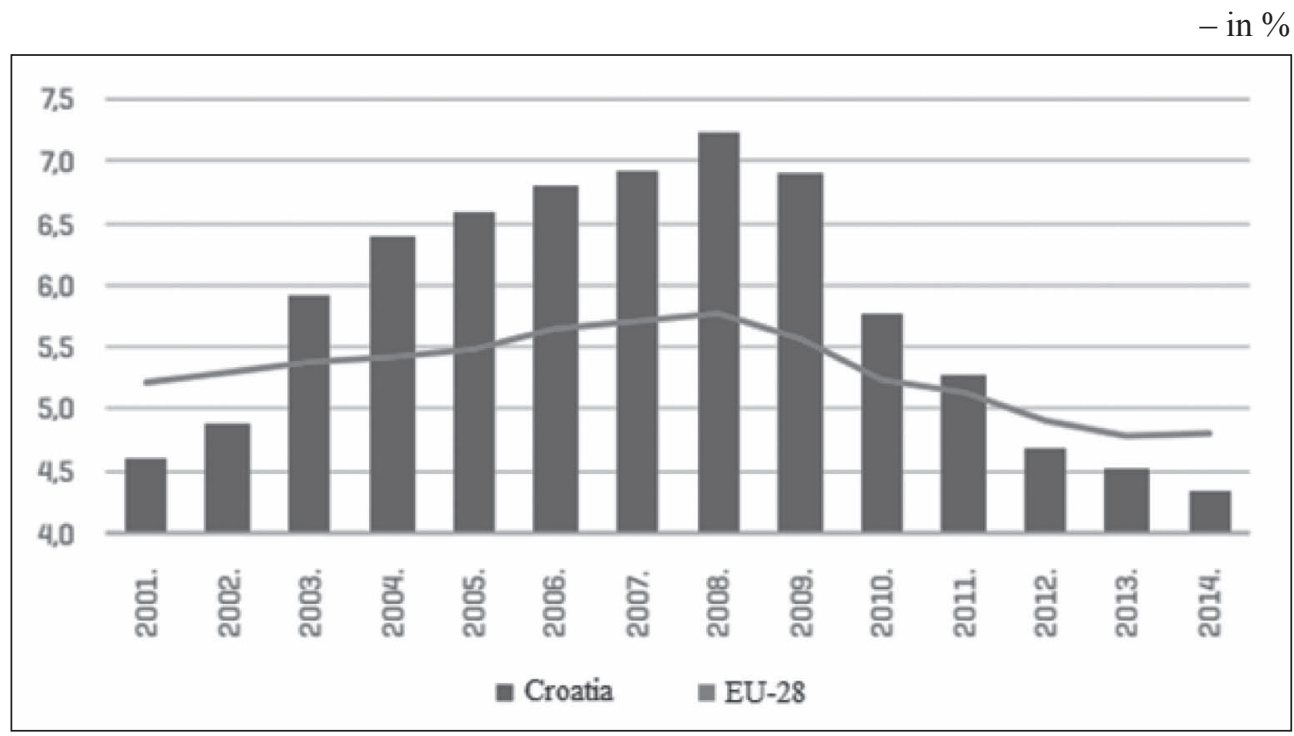

Source: Sector analyses (2015) The Institute of Economics, Zagreb - Croatia, Vol. 40(4), p. 6

The construction industry had lower total revenue than total cost and their ratio was getting lower by the year: 0, 99 in 2010, 0,96 in 2011 and 0.93 in 2012. Hence the construction industry had an insufficient efficiency which gets lower by the year. In 2011 the change in total revenue indicates the increase in business activity of $18,99 \%$; although revenue increased in 2012 , in comparison to 2011 , had been lower by $49,99 \%$. Operating profit margin in construction sector has fallen from $3,30 \%$ (in 2010) to $-3,46 \%$ (in 2012). That trend is present in all of the three specialized construction branches, although the operating profit margin of branch civil engineering had suffered the worst (the margin was $-9,17 \%$ ). Only specialized construction activity branch, in 2012, had a positive operating profit margin of $2,64 \%$ (which is still lower than the margin of 3,30\% it had in 2010). That trend is present in all of the three specialized construction branches, although the operating profit margin of branch civil engineering had suffered the worst (the margin was $-9,17 \%$ ). In the period from 2010 to 2012 productivity of labor and capital had been significantly falling. In that period productivity of labor had fallen by $22,03 \%$ while the productivity of capital suffered a decrease of $30,80 \%$. This was a result of a fall in gross value added by $31,40 \%$. Current ratio in the construction industry was very low during those years with a falling tendency. Quick ratio decreased from 0,612 (2010) to 0,528 (2012) in the construction industry. This indicates a struggle with servicing current liabilities from current assets (without stock). The gear ratio of the construction industry, for the given years, incessantly increases resulting in a total increase of $12 \%$. In all of the given years, the construction industry has a tendency 
of improving the export-import ratio resulting in higher exports than imports in 2012 (which was not the case in 2010 and 2011). In the three- year period from 2010 to 2012, the RCA index has increased in the construction industry from $-0,093$ to 0,287 which is still well below the 1 point mark. The only positive index, and by far the highest, has the civil engineering branch which correlates to its exportimport ratio that is above 1 .

Small businesses are $98,60 \%$ of the total market firms with $1,12 \%$ for mediumsized enterprises and $0,27 \%$ for large companies. Although the number of large companies is by far the lowest they employ $21,17 \%$ of the total employees in this industry. Therefore, the significance of large companies is undeniable - 32 large companies employ 16.921 workers. Despite the small number of large companies, they employ before mentioned $21,17 \%$ of the workers in the industry, comprising the $65,92 \%$ of the total construction industry assets; account for $53,64 \%$ of the exports, $20,33 \%$ revenue and $11,25 \%$ of the profits in the construction industry. Considering those numbers (assets, revenue, and profits) we can deduce that small and medium-sized enterprises use their assets more efficiently and are more profitable than the big companies.

Figure 4: Volume of construction works in Croatia, 2010 $=100$

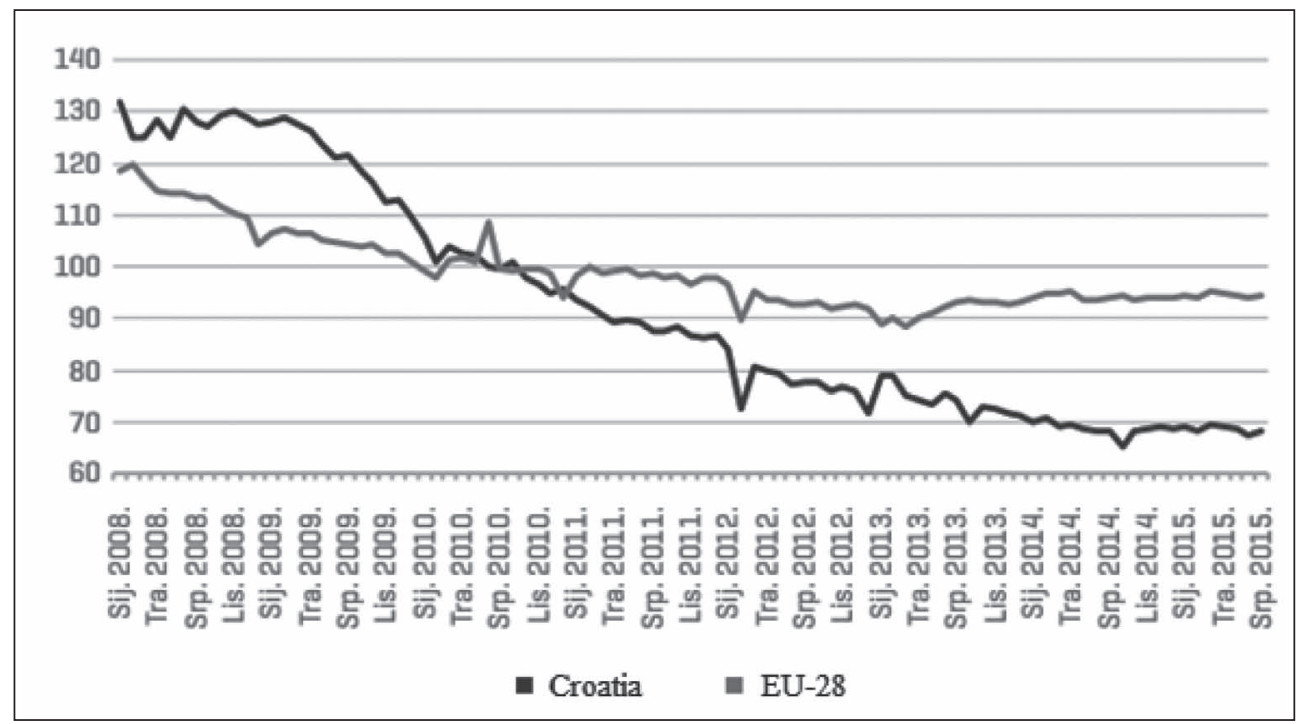

Source: Sector analyses (2015) The Institute of Economics, Zagreb - Croatia, Vol. 40(4), p. 4

Analyzing a certain set of quantitative indicators of the construction industry in Croatia and the appurtenant enterprises, specialized construction activity branch stands out in profitability and liquidity. Specialized construction activity branch 
employs $29,09 \%$ of the workers in construction, it is the only branch with revenue higher than the costs (1,02 ratio) which generates profit (61.178.420); positive ROA $(0,60 \%)$, ROE $(2,96 \%)$ and operating profit margin $(2,64 \%)$ even though that all efficiency indicators where decreasing. Liquidity is decreasing and on a very low level but still higher than the industry average. Gearing ratio of the branch is 0,7 and is higher than the construction industry average, interest coverage ratio is 4,25 which is way beyond that it is in other branches.

Figure 5: Share of construction sector employees in total employment number

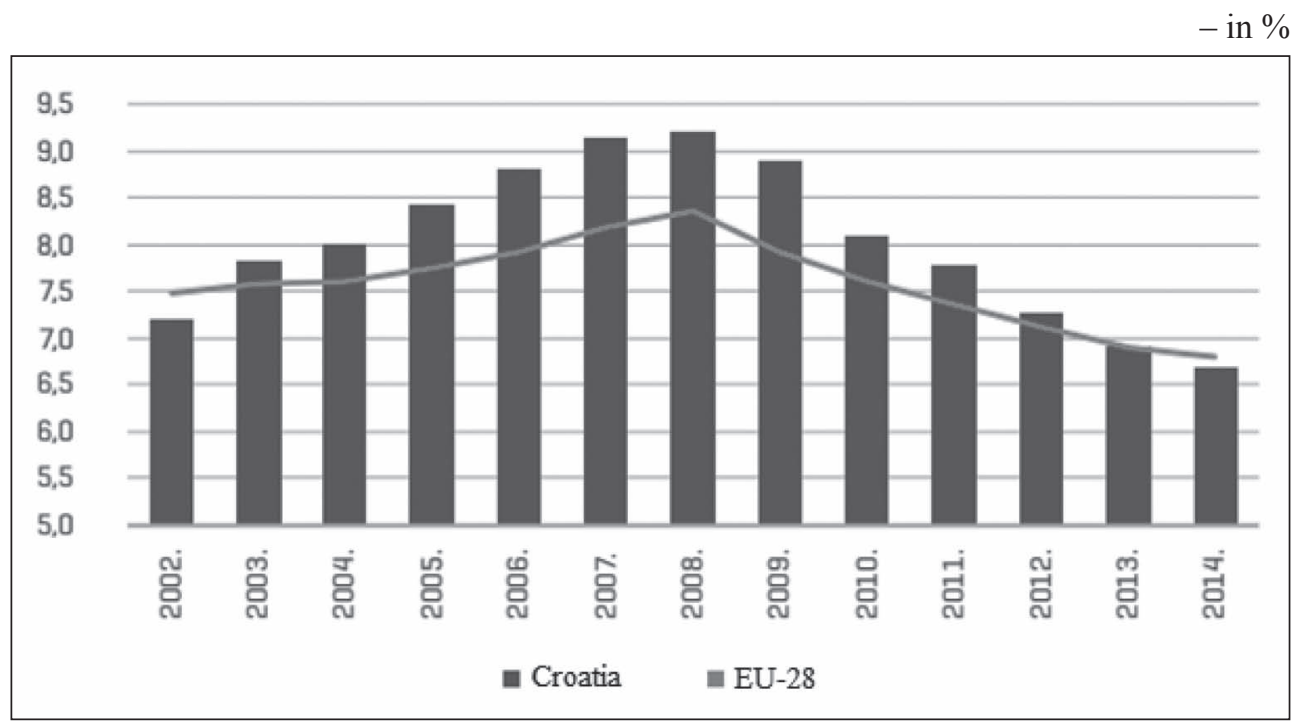

Source: Sector analyses (2015) The Institute of Economics, Zagreb - Croatia, Vol. 40 (4), p. 8

Specialized construction activity branch does not have competitive advantages as its RCA index is $-0,112$ (was -0,520); export-import ratio has increased (from 0,56 to 0,91 ) as did the trade balance of the branch (from -174.087.091 to -36.248.214); export share in total revenue of the branch is also increasing $(4,01 \%)$ as does it in the entire industry (from $17,39 \%$ to $25,18 \%$ ), international exchange takes place in similar branches (GL index 0,952). This branch has a lower share of gross added value $(25,89 \%)$ than in employment $(29,09 \%)$ of the construction industry. All the economic key factors contribution and government initiatives plans for construction industry should be a good benchmark for other industries to adhere certain factor that leads to good profitability indicators. 


\subsection{Empirical data}

The limitations of selected database from FINA have to be estimated with caution considering the information that firms in the pattern may be utilized for tax planning purposes preferably than for financial reports of a specific business entity. Correct evaluation of taxes for accounting will undoubtedly influence the econometric model results (Škuflić, Mlinarić, and Družić, 2016). This research uses quantitative data of 8678 construction companies for over 11 years (2003-2014) in Croatia. All data was exported from national agency for database of financial transactions (FINA). The Financial Agency (FINA) database contains tax return information on an annual base. Every financial entity in Croatia each year has to send data on wide range of financial activities such as income and expenses. These data are confidential and remote access was authorized under the specific research project.

It is obvious that chosen variables are result of industry qualifications and moreover the circumstances of national living standard, namely other determinant has dissimilar influence, intensity and correlation with profitability. This paper used the most relevant factors for firm profitability based on subjective valuation and scientific studies with same or similar topic in this scientific field with limitations.

Table 1: Variables and measurement

\begin{tabular}{|l|l|l|}
\hline \multicolumn{1}{|c|}{ Dependent variable } & \multicolumn{1}{c|}{ Measurement } & \multicolumn{1}{c|}{ Symbol } \\
\hline Profitability & Net profit after tax & net_profit_af_tax \\
\hline \multicolumn{3}{|c|}{ Independent variables } \\
\hline Profitability & Lagged net profit after tax (-1) & net_profit_af_tax L1 \\
\hline Concentration & Herfindahl-Hirschman index & hhi \\
\hline Growth & Sales growth rate & salesgrowth \\
\hline Size & Natural logarithm of total sales & logassets \\
\hline Market power & Price cost margin & pcm \\
\hline Material costs & Material costs in HRK & mater.costs \\
\hline
\end{tabular}

Source: Authors' calculations

In Table 1 selected variables and their measurements are presnted. Profitability is measured by net profit after tax and present dependent variable. As independent variables consider (1) Lagged net profit after tax; (2) Herfindahl-Hirschman index; (3) Sales growth, (4) Natural logarithm of total sales; (5) Price cost margin and (6) Material costs, but all of them use different measurement unit. 


\section{Results and discussion}

Literature on the profitability determinants for industries with different purposes have produced vary range of investigation results. For example, Grinyer and McMkiernan (1991) described and evaluated the determinants of profitability with results that market share, growth of sales, capital intensity, decentralization and working capital play a important role in firm profitability explaining. Brush et al. (1999) find that firm and industry correlate business profitability, but firm has the stronger influence. According to the size of the companies, and investment, some of the chosen variables have also influence profitability, for example lagged profitability, a major variable of current profit margins, and that concentration of industry is positively correlated to firm profits margins. Also according to the profit margins (McDonald, 1999) found to be pro-cyclical in concentrated industries but with a negative direction in opposite test. Similar, Feeny (2000) found a soundly positive correlation between capital volume, size and profits. In addition, Nunes, Serrasquerio and Sequeria (2009) discovered a positive correlation between profitability, size and growth. Furthermore, they underline that more firm liquidity will not have negative consequence for firm profit. But, from another point of view, firms with lower debt degree and fixed assets are more profitable. According on the obtained results, firm-level or industry-specific effects are the dominant element on firm profitability.

The Table 2 indicates similar results depending on dummy variables. There is a positive relationship between lagged profitability, concentration, size and growth with $1 \%$ significance and material costs with $5 \%$ significance. Contrarily, there is a negative but insignificant correlation between pcm and profitability. Mentioned results are for firms with less than 250 employees. In addition, we can observe similar results with some differentiation for bigger firms with more than 250 employees. Bigger firms' results show positive and significant correlation between lagged profitability, concentration, size, growth and pcm with $1 \%$ significance, where just material costs have negative relationship with profitability. The positive correlation between growth of total sales and profitability is consistent with Nunes et al. (2009) who suggested that when the growth of total sales increases it will also affect the profitability to increase as well, as it influences the employee's motivation to expect greater benefits and gains in the future. Table 2 presents results of empirical analysis.

The results are confirmed on both groups of observed firms. Also, same results are showed in Dogan (2013) who studied factors affecting profitability in Turkey and found a positive correlation between sales and profitability. The obtained results produced evidence of positive relationship between profitability and size. Firms with better profitability will become larger. It is also shown in McDonald (1999). Firm size affects company advantage of economies of scale and scope and procedures formalization and in return way what is also shown in this research. 
Table 2: Results of dynamic panel model (GMM)

\begin{tabular}{|c|c|c|c|c|c|c|}
\hline Variables & Coef. & Std. Err. & $\mathrm{z}$ & $P>|z|$ & \multicolumn{2}{|c|}{$95 \%$ Coef. Interval } \\
\hline \multicolumn{7}{|c|}{ Dummy $=0$} \\
\hline net_profit $\sim$ L1 & 0.3012732 & 0.0038407 & 78.44 & 0.000 & 0.2937456 & 0.3088008 \\
\hline mater_costs & 0.0079478 & 0.003685 & 2.16 & 0.031 & 0.0007254 & 0.0151703 \\
\hline salesgrowth & 67135.43 & 12916.35 & 5.20 & 0.000 & 41819.85 & 92451.01 \\
\hline hhi & $1.16 \mathrm{e}+11$ & $1.88 \mathrm{e}+09$ & 61.64 & 0.000 & $1.12 \mathrm{e}+11$ & $1.20 \mathrm{e}+11$ \\
\hline logassets & 68429.93 & 18481.53 & 3.70 & 0.000 & 32206.79 & 104653.1 \\
\hline pcm & -2.118211 & 1.32708 & -1.60 & 0.110 & -4.719239 & 0.4828174 \\
\hline cons & -926569.9 & 251447.1 & -3.68 & 0.000 & -1419397 & -433742.7 \\
\hline \multicolumn{7}{|c|}{ Dummy = 1} \\
\hline net_profit $\sim$ L1 & 0.1019792 & 0.0000133 & 7658.21 & 0.000 & 0.1019531 & 0.1020053 \\
\hline mater_costs & -0.0096933 & 0.0000582 & -.166 .52 & 0.000 & -0.0098074 & -0.0095792 \\
\hline salesgrowth & $1.75 \mathrm{e}+07$ & 32804.19 & 534.00 & 0.000 & $1.75 \mathrm{e}+07$ & $1.76 \mathrm{e}+07$ \\
\hline hhi & $5.72 \mathrm{e}+10$ & $1.06 \mathrm{e}+08$ & 539.56 & 0.000 & $5.70 \mathrm{e}+10$ & $5.75 \mathrm{e}+10$ \\
\hline logassets & $1.11 \mathrm{e}+07$ & 26584.34 & 416.17 & 0.000 & 803698.2 & 880846.3 \\
\hline $\mathrm{pcm}$ & 842272.3 & 19681 & 42.80 & 0.000 & 803698.2 & 880846.3 \\
\hline cons & $-2.21 \mathrm{e}+08$ & 553667.6 & -399.05 & 0.000 & $-2.22 \mathrm{e}+08$ & $-2.20 \mathrm{e}+08$ \\
\hline \multicolumn{3}{|c|}{ Sargan test (p-value) } & \multicolumn{4}{|c|}{0,6497} \\
\hline \multicolumn{3}{|c|}{ Arellano-Bond test 1 ( $\mathrm{p}$-value) } & \multicolumn{4}{|c|}{0,3372} \\
\hline \multicolumn{3}{|c|}{ Arellano-Bond test 2 (p-value) } & \multicolumn{4}{|c|}{0,4668} \\
\hline
\end{tabular}

Source: Authors' calculations using FINA statistical database

Lagged profitability and concentration (which is measured with HerfindahlHirschman index) are also tested in McDonald (1999) and results showed positive and significant relationship. Price cost margin, which is equal to the value of output minus the cost of labor and materials, divided by the value of output, has different influence depending on the number of employees. Concluding, in firms with less than 250 employees it does not have significant influence while in bigger firms there is a positive and significant influence (1\%).

Moreover, the significant influence of material costs on profitability suggests that is very important to focus on cost management to ensure higher levels of profitability. Next table summarizes results above and gives whole and concise picture of analyzed data. Summing up, the used model allows determination of the direction of the influence of independent variables on profitability for both tested groups. 
Table 3: Direction of influence of variables on profitability

\begin{tabular}{|l|c|c|c|c|}
\hline \multicolumn{1}{|c|}{ Variables } & Coefficient & Significance & Coefficient & Significance \\
\hline Number of firm employees & \multicolumn{2}{|c|}{$<250$} & \multicolumn{2}{|c|}{$250>$} \\
\hline Lagged net profit after tax & + & $* * *$ & + & $* * *$ \\
\hline Herfindahl-Hirschman index & + & $* * *$ & + & $* * *$ \\
\hline Sales growth rate & + & $* * *$ & + & $* * *$ \\
\hline $\begin{array}{l}\text { Natural logarithm of total } \\
\text { assets }\end{array}$ & + & $* * *$ & + & $* * *$ \\
\hline Price cost margin & - & & + & $* * *$ \\
\hline Material costs & + & $* *$ & - & $* * *$ \\
\hline
\end{tabular}

Note: $* 10 \%, * * 5 \%, * * * 1 \%$ significance

Source: Authors' calculations

The table above confirms used model like an appropriate model in which picked determinants have expected an effect on profitability and their relationship makes sense. Also, the model plausibly explains the direction of profitability changes influenced by changes of dummy variables which is confirmed with well used Sargan and Arellano-Bond tests.

\section{Conclusion}

The construction industry in general perspective is dynamic, large, expanding, divided, fluctuating and heterogeneous kind of industry. Like in other industries, profitability is the top target for every firm management. For higher profits which increases firm value, it is needed to focus on profitability, that is their significant variables. According to that, the research findings are more important. This paper examines construction industry in Croatia through the determinants of profitability which are analyzed with dynamic panel data method. A generalized method of moments is used on a sample of 8678 construction firms in the period between 2003 and 2014 what gives 56329 observations. The most important contribution of this survey is their results with all his limitations. It gives the picture determinants which are most affecting financial results of construction firms in the Republic of Croatia in observed period of time with positive econometric test results.

The research was divided into two parts, one for firms with less than 250 employees and second for firms with more than 250 employees. The main purpose of classification was to see if there is any difference according to the size of firms measured with a number of employees because it is well known that there are a lot of differences which distinguish small and medium firms from bigger ones. It 
is picked up by 250 employees because of Croatian statistic database framework and estimated calculation based on the size of the national economy and other specific country characteristics. The results showed a positive strong correlation between lagged profitability, Herfindahl-Hirschman index, the natural logarithm of total assets, sales growth and profitability for firms which have less than 250 employees. Only material costs variable provided a positive relationship with 5\% of significance. Variable price cost margin did not show significant influence on profitability. According to the results for other firms with more than 250 employees, it is obvious that all selected variables showed a strong correlation with profitability. Lagged profitability, Herfindahl-Hirschman index, the natural logarithm of total assets, price-cost margin and sales growth have a strong positive relationship of $1 \%$ significance with profitability while just variable material costs have a negative relationship with profitability. All showed results were confirmed with Sargan and Arellano-Bond tests with the conclusion that lagged profitability, size of the firm, firm's growth and concentration have predictable output according to profitability independently on a number of firm`s employees.

Given and described results are in line with previous investigations in the same scientific field. For future studies, a precondition is to exceed limitations from this research. First of all, there is restriction according to the available useful data (lack of publicly available official data). The limitations of the selected database from FINA have to be rated with caution considering the information that some firms in the pattern may be taken into account for tax planning purposes preferably than for financial reporting. Also, provided results are determinate with chosen variables, although chosen variables in this research are very similar to other studies. For this kind of study chosen econometric GMM showed the best efficient results above others. For next research iteration, it is open to use some other dynamic model. Generally, this paper provides useful information and knowledge to future studies in this area where there is still plenty of room for further researches according to the used methodology and problem with employee dispersion through construction companies. This paper will be beneficial to different stakeholders such as individuals, private and public institutions, official government representatives and scientific as well. It provides an understanding of the variables that affect financial performance which focuses on profitability. Surely, stakeholders have to pay attention to obtained variables in order to achieve successful management goals in construction firms in Croatia.

\section{References}

Arellano, M., Bond, S.R. (1991) "Some Tests of Specification for Panel Data: Monte Carlo Evidence and an Application to Employment Equations", Review of Economic Studies, Vol. 58, No. 2, pp. 277-297, doi: 10.2307/2297968. 
Arellano, M., Bover, O. (1995) "Another look at the instrumental variable estimation of error-components models", Journal of Econometrics, Vol. 68, No. 1, pp. 2951, doi: 10.1016/0304-4076(94)01642-d.

Bain, J.S. (1956) “Barriers to New' Competitors: Their Character and Consequences in Manufacturing Industries", Cambridge: Harvard University Press, doi: 10.4159/harvard.9780674188037.

Blundell, R., Bond, S. R. (1998) "Initial conditions and moment restrictions in dynamic panel data models", Journal of Econometrics, Vol. 87, No. 1, pp. 115143, doi: 10.1016/s0304-4076(98)00009-8.

Brush, T.H., Bromiley, P., Hendrix, M. (1999) "The relative influence of industry and corporation on business segment performance: An alternative estimate", Strategic Management Journal, Vol. 20, No. 6, pp. 519-547, doi: 10.1002/ (sici)1097-0266(199906)20:6<519::aid-smj32>3.0.co;2-8.

Dogan, M. (2013) "Does Firm Size Affect The Firm Profitability? Evidence from Turkey", Research Journal of Finance and Accounting, Vol. 4, No. 4, pp. 53-59.

Feeny, S. (2000) "Determinants of Profitability: An Empirical Investigation Using Australian Tax Entities", Melbourne Institute Working Paper, No. 1/00.

FINA database (2016) Offical statistical package for academic users, Zagreb.

Grinyer, H.P., McKiernan, P. (1991) "The determinants of corporate profitability in the UK electrical engineering industry", British Journal of Management, Vol. 2, No. 1, pp. 17-32, doi: 10.1111/j.1467-8551.1991.tb00012.x.

Hansen, G.S., Wernerfelt, B. (1989) "Determinants of firm performance: the relative importance of economic and organizational factors", Strategic Management Journal, Vol. 10, No. 5, pp. 399-411, doi: 10.1002/smj.4250100502.

McDonald, J.T. (1999) "The determinants of firm profitability in Australian manufacturing", The Economic Record, Vol. 75, No. 229, pp. 115-126, doi: 10.1111/j.1475-4932.1999.tb02440.x.

McGahan, A.M., Porter, M.E. (2002) "What do we Know About Variance in Accounting Profitability", Management Science, Vol. 48, No. 7, pp. 834-851, doi: $10.1287 / \mathrm{mnsc}$.48.7.834.2816.

Nunes, P.J.M., Serrasquerio, Z.M., Sequeira, T.N. (2009) "Profitability in Portuguese service industries: A panel data approach", The Service Industries Journal, Vol. 29, No. 5, pp. 693-707, doi: 10.1080/02642060902720188.

Porter, M.E. (1981) "The contributions of industrial organization to strategic management", Academy of management review, Vol. 6, No. 4, pp. 609-620, doi: 10.5465/amr.1981.4285706.

Ravenscraft, D.J. (1983) "Structure-profit relationships at the line of business and industry level", Review of Economics and Statistics, Vol. 65, No. 1, pp. 22-31, doi: $10.2307 / 1924405$.

Scherer, F.M. (1980) Industrial Market Structure and Economic Performance, $2^{\text {nd }}$ edition, Chicago: Rand-McNally. 
Schmalensee, R. (1989) "Inter-Industry Studies of Structure and Performance", in Schmalensee, R. and Willig, R.D. (ed.) Handbook of Industrial Organization, Vol. 2, pp. 951-1009, doi: 10.1016/s1573-448x(89)02004-2.

Sector analysis (2015) Croatia: Economic Institute Zagreb, Vol. 40 (4).

Stierwald, A. (2009) "Determinants of firm Profitability: The Effect of Productivity and its Persistence", Melbourne Institute for Applied Economic and Social Research.

Škuflić, L., Mlinarić, D. (2015) "Microeconomic determinants of profitability for Croatian hotel industry", Economic review, Vol. 5, No. 5, pp. 477-494.

Škuflić, L., Mlinarić, D., Družić, M. (2016) "Determinants of Firm Profitability in Croatia's Manufacturing Sector”, ICESoS 2016 Proceedings Book, pp. 269-282. 


\title{
Odrednice profitabilnosti građevinskog sektora u Hrvatskoj
}

\author{
Lorena Škuflić ${ }^{1}$, Danijel Mlinarić ${ }^{2}$ Marko Družić ${ }^{3}$
}

\begin{abstract}
Sažetak
Ovaj rad istražuje odrednice profitabilnosti građevinskog sektora u Republici Hrvatskoj. Promatrani i istraživani uzorak uključuje 8678 građevinskih tvrtki iz Hrvatske u razdoblju od 2003. do 2014. godine, što predstavlja 11 godina promatranja. Navedeno razdoblje uključuje i važne događaje za dobivene rezultate $i$ interpretaciju, poput pridruživanja Hrvatske Europskoj uniji kao i svjetsku financijsku krizu. Predstavlja se teorijska podloga istraživanju te se provodi ekonometrijska analiza koja metodološkim razgraničenjem istražuje povezanost profitabilnosti tvrtki i izabranih odrednica poput odnosa cijene i troška, indeksa koncentracije, rasta, veličine, materijalnih troškova i profitabilnosti s vremenskim odmakom. Posebno je razrađeno stanje u građevinskom sektoru Republike Hrvatske kao i njena važnost za ekonomski prosperitet države, a sve s reperkusijama svjetske financijske krize. Empirijski dio istraživanja koristi generaliziranu metodu momenata dinamičkog ekonometrijskog panela koji pokazuje statistički značajne rezultate. Zaključno, rezultati pokazuju snažnu povezanost između veličine poduzeća, indeksa koncentracije, rasta lagirane profitabilnosti i profitabilnosti nevezane za broj zaposlenih.
\end{abstract}

Ključne riječi: građevinski sektor, profitabilnost, Hrvatska, ekonometrijska panel analiza

JEL klasifikacija: L21, L25, L74

${ }_{1}$ Redovna profesorica u trajnom zvanju, Sveučilište u Zagrebu, Ekonomski fakultet, Trg J. F. Kennedyja 6, 10000 Zagreb, Hrvatska. Znanstveni interes: industrijska organizacija, konkurentnost. Tel.: +38512383 115.E-mail: lskuflic@efzg.hr.

2 Docent, Sveučilište u Zagrebu, Ekonomski fakultet, Trg J. F. Kennedyja 6, 10000 Zagreb, Hrvatska. Znanstveni interes: industrijska organizacija, sustavni rizik, konkurentnost bankovnog sektora.Tel.: +38512383 127.E-mail:dmlinaric@efzg.hr.

3 Docent, Sveučilište u Zagrebu, Ekonomski fakultet, Trg J. F. Kennedyja 6, 10000 Zagreb, Hrvatska. Znanstveni interes: mikroekonomija.Tel.: +38512383 129. E-mail: mdruzic@efzg.hr. 